\title{
Dijital Aktivizm: Change.org Kampanyaları Üzerine Bir Analiz
}

Digital Activism: An Analysis of Change.Org Campaigns in Turkey

\author{
Prof. Dr. Emet Gürel ${ }^{1}$ - Arş. Grv. Azra Nazlı ${ }^{2}$
}

Başvuru Tarihi: 07.04.2019

Kabul Tarihi: 30.12.2019

\section{Öz}

İnternet ve yeni iletişim teknolojileri, çă̆gl dünyanın önemli gündem maddelerinden biridir. Toplumsal değişime yönelik etkili bir katalizör olarak kabul edilen internet, işi ve işin yapılma şeklini değiștirerek yeni bir düzenin kurulmasını sağlamaktadır. Yaşama dair tüm olay ve olgular, yeni dünyaya özgü bu yeni platform üzerinde varlık göstermektedir. Öyle ki internet, aktivizm hareketleri için de bir mecra görevi görmektedir. Aktivizm, en yalın ifadeyle bireylerin ve toplumların daha güzel ve daha iyi bir dünya ümidinden beslenen eylemciliktir. 'Dijital aktivizm' olarak adlandırılan yeni aktivizm anlayışı, birey ya da örgütlerin arzuladıkları toplumsal değişimi yaratmak amacıyla dijital ortamda gerçekleştirdikleri etkinlikleri tanımlamaktadir. Slaktivizm -slactivism-, kliktivizm -clictivism-, taraf olma/savunuculuk aktivizmi -advocacy-, hashtag aktivizmi -hashtag activism-, hacktivizm -hacktivism-, infoaktivizm -information activism-, maptivizm -maptivism- ve aplikasyon aktivizmi -apptivismgibi kavram ve etkinlikleri kapsayan dijital aktivizm aracılı̆̆ ile toplumsal değissim hareketleri farklı bir niteliğe bürünmektedir. Geniş kitlelere kolaylıkla ve hızla ulaşması, çok sesliliğe izin vermesi, farklı şekil ve yöntemlerle gerçekleştirilebilmesi, sosyal medya kanallarında çapraz paylaşılabilmesi dijital aktivizmin her geçen gün daha da yaygınlık kazanması sonucunu doğurmaktadır. Bu çalışma, dijital aktivizm kavramını mercek altına almakta ve söz konusu kavramı Change.org kampanyaları ïzerinden analiz etmeyi amaçlamaktadır. Araştırma, nitel desende tasarlanmuştır ve betimsel analiz ile uygulanmıştır. Araştırmada elde edilen bulgular, belirli kategoriler oluşturularak yorumlanmış ve bulgulara ilişkin detaylar, çalışmanın sonuç kısmına yansıtılarak dijital aktivizme ilişkin çıkarımlar yapılmıştır. Çalışma, dijital aktivizmin Türkiye’deki yansımaları ve gelecek çalışmalara yönelik öneriler ile sonlanmaktadır.

Anahtar Kelimeler: Aktivizm, dijital aktivizm, Change.org

\section{Abstract}

The Internet and new communication technologies are among the most important topics of the modern world. The Internet is considered an effective catalyzer of social change and is establishing a new order by changing work and the way it is done. All events and phenomena

\footnotetext{
${ }^{1}$ Ege Üniversitesi İletişim Fakültesi Halkla İlişkiler ve Tanıtım Bölümü, emet.gurel@ege.edu.tr ORCID: 0000-0002-5120-8042

2 Ege Üniversitesi İletişim Fakültesi Halkla İlişkiler ve Tanıtım Bölümü, azrakardelen.nazli@ege.edu.tr 0RCID: 0000-0003-0565-1278
} 
on life exist on this platform that is peculiar to this new world. The Internet serves as a channel for activism. In its simplest definition, activism is an act that is nourished from the individuals and societies' hope for a better and more desirable world. The new understanding of activism known as digital activism refers to activities performed on digital media to realize social changes that individuals and organizations want. Social change activities through digital activism contain notions and activities such as slactivism, clicktivism, advocacy, hashtag activism, hacktivism, information activism, maptivism, and apptivism. Reaching large masses easily and quickly, letting many people speak out, performing in different ways and methods, cross sharing on social media channels allow digital activism to enlarge each and every day. This study focuses on digital activism and aims to analyze this concept in Change.org campaigns. The study is designed in a qualitative method and is a descriptive analysis as a format. The data was interpreted in specific categories and deductions were made about digital activism reflecting details regarding the findings in this study's conclusion, which ends with the reflections on digital activism in Turkey and recommendations for future researches.

Keywords: Activism, digital activism, Change.org

\section{Giriş}

\section{"Direniyorum, o halde varım!" \\ - “Resisto ergo sum!”-}

Aktivizm, en yalın ifadeyle toplumsal değişim istenciyle gerçekleştirilen mücadeledir. $\mathrm{Bu}$ mücadele yakıtını, insanın direnen bir varlık olmasından almaktadır. Felsefi ifadeyle ise insan, direnen hayvandır. Camus (1997), insanı tam da bu bağlamda tanımlamaktadır: 'Boşuna olduğu halde direnen insan'. Ona göre yaşamın anlamı ancak, dünyanın saçmalığını ve yenilginin daima tekrarlanacağını bile bile kötülüŭge direnmektir; insanlığa gerçek boyutlarını ancak bu başkaldırı kazandırabilmektedir. İnsan doğasına koşut bir niteliği olan ve insanın daha iyi bir dünya arayışı ile karşılık bulan aktivizm; bir 'dünya görüşü', bir 'felsefi yönelim', bir 'eylem doktrini' ve bir 'toplumsal hareket biçimi' olarak nitelenebilmektedir. Aktivizm, tarihsel anlamda yeni bir olgu değildir ve köken olarak 19. yüzyıl ile birlikte başlayan toplumsal hareketlere dayanmaktadır. Bununla birlikte aktivizm, toplumsal değişim ve dönüşümlere koşut olarak evrilen bir yapıya sahiptir. Günümüzdeki anlamıyla aktivizm, geçmişe kıyasla daha teknolojik bir yönelimdedir. Yeni dünya düzeninin dinamiklerine koşut olarak gündeme gelen yeni aktivizm, dijital platformlara uyarlanan ve çağcıl toplumun sorun olarak algıladığ konulara yönelik kendini ifade etmesine olanak tanıyan bir niteliktedir. Bu bağlamda aktivizm, internet kullanımın yaygınlaşması ve yeni medya kanallarının ortaya çıkması ile hibrit bir yapıya bürünmüştür. Yeni medya ortamları; bireye hareket özgürlüğü, anında ve sürekli erişim imkanı, interaktivite şansı vermektedir. Böylelikle birey; fikrini, duygusunu, düşüncesini ifade etme amacıyla etkileşimli medya araçlarına daha fazla yönelmektedir. Çevrim içi sosyal ağlardaki büyüme ise, bireylere toplumsal konularda birlikte hareket etmek için bir dayanak noktası oluşturmaktadır. 


\section{Aktivizm}

Aktivizm, toplumsal değişim arzusuyla kasıtlı olarak yapılan eylemdir. Daha geniş tanımıyla aktivizm, kişilerin kurum ya da kuruluşlar üzerinde baskı yaratarak sorunlu gördükleri politika, uygulama ya da durumları değiştirmeye yönelik çabalarıdır. Aktivizm etkinliklerine temel teşkil edebilen ve sorunlu olduğu düşünülen alan ve konular, oldukça çeşitli olabilmektedir. Öyle ki ekonomi, politika, din, çevre, ,rk ve toplumsal cinsiyet gibi alan ve konular aktivizme konu olabilmektedir. Bu durum aktivizm hareketlerinin, yaşamın her alanına yayılacak denli zengin ve kapsamlı olması sonucunu doğurmaktadır.

Aktivizm, Türk Dil Kurumu Türkçe Sözlük'te (2019) Fransızca ‘activisme’ kelimesinden Türkçe'ye girmiş bir kelime olarak gösterilmiş ve "eylemcilik” olarak karşılık bulmuştur. Eylemcilik ise, "eylemci olma durumu” olarak açıklanmıştır. Sert'e (2016) göre ise "aktivizm; toplumun ortak çıkarlarını tehdit eden bir sorunu çözebilmek adına gönüllü olarak örgütlenmiş bir grup insanın kamuların dikkatini çekebilmek ve soruna neden olan uygulamaları etkileyebilmek ya da istenen yönde değiştirebilmek için yürüttükleri mücadeledir”.

Aktivizm, bir eylemlilik halidir ve bir özne aracılığıyla hayata geçmektedir. Aktivizmin temel aktörü, aktivisttir. Bu bağlamda aktivist -activiste-, aktivizm hareketlerine aktif olarak katılan kişi olarak tanımlanabilmektedir. Türkçede 'etkinci' olarak da adlandırılan bu kişi; aktivizm hareketinin kapsamı, türü, etkinliği gibi konularda belirleyici bir rol üstlenmektedir.

Aktivizm, temelde felsefi içeriğe sahip bir kavramdır. Akarsu (1975, s. 72) aktivizmi; "insan yaşamı ve düşüncesinin başlıca gerçekliğinin etki, eylem ve yapıp etmelerde olduğunu öne süren öğreti ve dünya görüşü’” olarak tanımlamaktadır. Hançerlioğlu (1994, s. 96) ise aktivizmi, 'etkincilik' olarak Türkçeleştirmekte ve “gerçeği eylemsel etkinliklerde bulan öğretilerin genel adı" olarak nitelemektedir.

Aktivizm anlayışı, felsefe tarihinde değişik biçimlerde ortaya çıkmıştır. Bu bağlamda Fichte'de dogmacılığa, doğalcılığa ve özdekçiliğe karşı düşüncel biçimde temellendirilmiştir. Nietzsche'de anlıkçılığa karşı gerçekçi-istenççi biçimde ifade bulmuştur. Marx'ta ise tüm kuramsal dünya görüşlerine karşı gerçekçi-özdekçi biçimde, dünyayı tanımak ve yorumlamak yerine değiştirmek isteyen bir dünya görüşü olarak belirmiştir. Öyle ki bir etkinlik ve eylem felsefesi olan Marxcılığa göre insan, eylemde bulunarak insanlaşmıştır (Akarsu, 1975, s. 72; Hançerlioğlu, 1994, s. 97).

Aktivizminin felsefi geçmişi eskiye dayansa da, bir eylem biçimi olarak toplum sahnesinde girmesi görece yakın bir dönemde olmuştur. İnsanın daha iyi, daha güzel ve daha eşit bir dünya arayışı evvel ezel var olmuştur. Ancak bu arayışın toplumsal bir nitelik kazanması ve kitleselleşmesi, 19. yüzyılda gerçekleşmiştir. Öyle ki Giddens da toplumsal hareketlerinin büyük oranda çağdaş dünyanın bir özelliği olduğuna dikkat çekmektedir. Giddens'a (2000, s. 540) göre "toplumsal hareket; yerleşik kurumlar alanının dışındaki toplu eylemler yoluyla, ortak bir çıkarı korumak ya da ortak bir hedefe erişmeyi sağlayabilmek için girişilen toplu bir çabadır".

Toplumsal hareketler, 19. yüzyılda gerçekleşen işçi hareketleri ile başlatılmaktadır. Sanayi Devrimi'nin gerçekleşmesi, büyük bir toplumsal dönüşüme neden olmuş ve kitleler üzerinde sarsıcı bir etki yaratmıştır. Sanayi Devrimi ile ortaya çıkan işçi sınıfı, toplumsal hareketlerin oluşumunda önemli bir rol üstlenmiştir. Ludizm hareketleri, bu kapsamda örnek olarak 
verilebilmektedir. Ludizm, Sanayi Devrimi’nin beraberinde getirdiği koşullara ve kapitalizmin gelişimine tepki olarak İngiltere'de gerçekleşen ve 1811-1816 yılları arasında en hareketli dönemini yaşayan makine kırıcılık temelli toplumsal bir harekettir (Gürel ve Muter, 2013).

Toplumsal hareketleri, tarihsel süreçte ortaya çıkışları ve nitelikleri açısından 'eski toplumsal hareketler' ve 'yeni toplumsal hareketler' olmak üzere ikiye ayırarak incelemek mümkündür. 'Eski toplumsal hareketler', toplumsal hareketlerin ilk ortaya çıktıkları dönem olan 19. yüzyıl ile tarihlenmektedir. Bu hareketler; siyasal iktidarı hedefleyen ve ekonomik karakteristiği olan sınıfsal yapılı hareketlerdir. 'Yeni toplumsal hareketler' ise, 1970'lerden itibaren ortaya çıkan hareketlerdir. Yeni toplumsal hareketler; ekoloji hareketlerini, feminist hareketi, barış hareketini, nükleer karşıtı hareketi, azınlık hareketlerini ve yerel özerklik hareketlerini ifade etmektedir (Karagöz, 2013, s. 134).

\section{Dijital Aktivizm}

Teknolojik gelişmeler ve internetin gelişimi, aktivizm kavramına ve aktivizm hareketlerine farklı bir açılım getirmiştir. 1990'lı yıllardan itibaren internetin toplumsal yaşama hakim olması, yaşama dair tüm alanlarda etkisini hissettirdiği gibi, toplumsal hareketleri de değiştirmiştir. Yeni iletişim teknolojileri ve internet, toplumsal sorunların görünürlüklerini ve insanların söz konusu sorunlara yönelik hassasiyetlerini arttırmıştır. Katılımcılık, çok seslilik ve demokrasi gibi kavramların geçmişe kıyasla daha fazla konuşulduğu bu dönemde insanlar, sorunların çözümüne daha fazla dahil olmaya başlamışlardır.

Yeni ve küresel dünyaya özgü aktivizm hareketleri, dijital aktivizm -digital activism- olarak adlandırılmaktadır. 'Aktivizm 2.0' olarak da adlandırılan bu dönemin belirleyici niteliği, aktivizm hareketlerinin internet ve sosyal medya aracılığıyla gerçekleştirilmesidir. Dijital aktivizm; internet ortamında toplumsal ya da politik konularda, karşı ya da taraf olmanın yanı sıra herhangi bir konuda kişilerin fikirlerini değiştirmeye yönelik etkileme çabası olarak tanımlanabilmektedir (Çoban ve İnceoğlu, 2015, s. 13). Dijital aktivizm hareketleri, eski dönem aktivizm anlayışı üzerinde temellenen ve yeni dönem aktivizm hareketlerinin çeşitliliğinden beslenen niteliktedir.

Jenkins (2016, s. 2), 1960’lı y1llardan itibaren aktivizm hareketlerinin dilinin popüler kültürden beslendiğini ifade etmekte ve karşıt bir kültürünün doğuşuna dikkat çekmektedir. Ona göre günümüz siber kültürü temelini 60'lardan almaktadır ve 90'ların getirdiği 'Kendin yap' - 'Do it yourself'- akımı aktivizm hareketlerini beslemektedir. Bu bağlamda günümüzde aktivizm hareketleri, katılımcı kültürünün dönüştürücü gücü ile oyuncu bir kimliğe bürünmektedir.

Joyce (2010, s. 2) ise, dijital aktivizmin araçsal yapısına dikkat çekmektedir. Ona göre "dijital aktivizm; hem belirli bir aktivizm kampanyasında kullanılan dijital teknolojiye, hem de böyle bir teknolojinin kullanıldığı ekonomik, sosyal ve politik içeriğe atıfta bulunmaktadır. Dijital teknolojinin altyapısı dijital aktivizmin fiziksel altyapısını oluşturan ağların, kodların, uygulamaların ve cihazların birleşimi-; aktivizm için bir başlangıç noktasıdır ve bunun yanında ekonomik, sosyal ve politik farklılıkları aktivistlerin bu teknolojiyi kullanma şeklini de belirlemektedir".

'Dijital aktivizm' kavramı, araştırmacılar tarafından dijital araçlar ile gerçekleştirilen aktiviteleri tanımlamada yetersiz bulunmakla birlikte; gerçekleştirilen eylemin araçsallığı, hızı ve internet temelli olması nedeniyle maliyet düşüklüğünü ifade etmesi açısından 
kullanılagelmiştir. Bu bağlamda kapsamlı ve ayrıcalıklı doğası nedeniyle 'dijital aktivizm', dijital ağ altyapısını kullanan tüm aktivizm örneklerini tanımlamak için en uygun terim olarak halen kabul görmektedir (Shah vd., 2013, s. 296).

Dijital aktivizmde, eski aktivizm ve yeni aktivizm uygulamalarında olduğu üzere eylem ve protestolara fiziksel olarak katılmak söz konusu değildir. Dijital aktivistler herhangi bir konu ya da duruma ilişkin eylem ve protestolarını bilgisayar ekranında yorum yazarak; herhangi bir yazıyı beğenerek -like ederek-; yeniden göndererek -forward ya da retweet ederek-; imza kampanyaları düzenleyerek ya da imza kampanyalarına katılarak; haber, yazı, fotoğraf, video vb. paylaşarak göstermektedirler. Dolayısıyla dijital aktivistlerin ilgi, eylem ve etki alanlarının yalnızca kendi çevreleri ile sınırlı olduğunu ifade etmek mümkündür.

Literatürde, dijital aktivizme yönelik farklı görüşler bulunmaktadır. Bu kapsamda dijital aktivizme yönelik 'iyimser', 'kötümser' ve '1srarcı' olmak üzere üç görüş vardır. Söz konusu görüşler, dijital aktivizm kavramının kapsamı ve geleceği açısından önem arz etmektedir. İyimser bakış açısına göre, dijital dünyanın ağa bağlı doğası, insanların geleneksel hiyerarşik güç yapıları dışında ve bazen de buna muhalif olarak iletişim kurmalarını ve harekete geçmelerine destek olmaktadır. Hiyerarşik açıdan üsttekiler alttakiler üzerindeki güce sahipken; ağlarda güç dağılımı daha dengelidir. Bu görüşe göre internet; kamu söylemini, bireylerin kitle iletişim araçlarından daha fazla söz sahibi olacağı şekilde yeniden yapılandırmaktadır (Benkler, 2006, s. 271).

Kötümser bakış açısında göre dijital aktivizm, kişileri internet üzerine yeniden düşünmeye sevk etmektedir. Bu çerçevede Morozov (2010), dijital teknolojilerin yeni gözetim alanları açtı̆̆ını dile getirmektedir. Çevrim içi gerçekleştirilen eylemlerin kırılganlığına da dikkat çeken Morozov, dijital ortamda söz konusu olan organizasyon eksikliklerinin gerçekleştirilen aktivist hareketin zayıflığının ortaya çıkmasına sebep olacağını ifade etmektedir.

Dijital aktivizm konusunda 1srarcı görüşe sahip olanlar ise, kötümser görüşe paralel bir şekilde düşünmektedir. Israrcı görüşü savunanlar, dijital aktivizmin etkisini olumlamakla birlikte; ağ teknolojisinin aktivizmin pratiğinin değişmesine aracılık ettiğine dikkat çekmektedirler. Onlara göre; mobilizasyon, organizasyon ve mesaj yayma gibi etkenlerle dijital aktivizmin mevcut çevrim dışı taktikleri daha etkili kılmaktadır (Shah vd., 2013, s. 300).

\section{Dijital Aktivizm Türleri}

Yeni dünyanın aktivizm şekli olan dijital aktivizm, sorunlu bulunan politika, uygulama ve durumların değiştirilmesine yönelik internet ve sosyal ağlar kullanılarak gerçekleştirilen eylemler olarak tanımlanabilmektedir. Dijital aktivizm, birçok mecra ve ağ üzerinden farklı yöntemlerle uygulanabilmektedir. Dolayısıyla dijital aktivizmin birçok türü bulunmaktadır. Bununla birlikte dijital kanal ve ağların gelişmesine koşut olarak yeni dijital aktivizm türlerinin de ortaya çıktığını ifade etmek mümkündür.

Laer ve Aelst (2010, s. 1148-1151); internet ve sosyal hareketler üzerine geliştirdikleri tipoloji ile dijital toplumsal hareketlere yönelik bir repertuar oluşturmuşlardır. Onlara göre bu tipolojinin iki boyutu bulunmaktadır. Birinci boyut, hareketin 'internet destekli' ya da 'internet temelli’ olmasına ilişkindir. İkinci boyut ise, aktivist hareketin içerdiği bağlılık, risk ve efor gibi etmenler temelinde belirlenen eşiktir. Söz konusu eşik, düşük ya da yüksek olabilmektedir. $\mathrm{Bu}$ bağlamda internet destekli aktivizm hareketleri düşük eşikten yükssek eşiğe doğru 
ilerleyebilmekte ve katılımcınının aktivist harekete bağışta bulunmasından saldırgan eylemlere dek uzanabilmektedir. İnternet temelli aktivist hareketler düşük eşikten yüksek eşiğe doğru ele alındığında çevrimiçi imza kampanyalarından, hacktivizm hareketlerine uzanan bir doğrusallık üzerinde gelişmektedir.

Tüm bu bilgilerin ışığında dijital aktivizm; slaktivizm -slactivism-, kliktivizm -clictivism-, taraf olma/savunuculuk aktivizmi -advocacy-, hacktivizm -hacktivism, info-aktivizm -info-activism-, maptivizm -maptivism- ve aplikasyon aktivizmi -apptivism- gibi kavram ve etkinlikleri kapsamaktadır. Dijital aktivizm kavramını ve kapsamını açılamak için, söz konusu kavram ve uygulamalara değinmekte yarar vardır.

Slaktivizm ve Kliktivizm: 'Slaktivizm' ve 'kliktivizm', dijital aktivizmin en yaygın türlerindendir. Her iki kavram birbiriyle benzeştiği için, bu çalışma kapsamında aynı kategoride ele alınmış ve açıklanmıştır. Slaktivizm kavramı, İngilizce 'slacker' kelimesi ve 'aktivizm' kelimesinin birleştirilmesi ile oluşturulmuştur. Kavramın öncel kelimesi olan 'slacker'; tembel, haylaz, miskin anlamlarına gelmektedir. Kelime, Oxford İngilizce Sözlüğ̈̈’nde (2019), "çalışmaktan ve çaba sarf etmekten kaçınan kişi”" olarak ifade bulmaktadır.

Slaktivizm kavramı Oxford İngilizce Sözlüğü’nde (2019), "politik ya da sosyal bir eylemi çok az çaba ve adanmışlık ile karakterize olarak sosyal medya ya da çevrim içi kampanyalar aracılığı ile destekleme pratiği” olarak tanımlanmışır. Christensen (2011); slaktivizm kavramını, ilk kez 1995 yılında Fred Clark ve Dwight Ozard tarafından 'slacker activism' kavramı için kısaltma olarak kullanıldığını ifade etmiştir. Onlara göre gençlerin toplumu etkilemek amacıyla başvurdukları ve tekilden çoğula ilerleyen bir niteliğe sahip olan etkinlikleri tanımlayan bu kavram, olumlu bir çağrışıma sahiptir. Yegen'e (2014, s. 90) göre ise "slaktivizm, durduğu yerden dijital bir eylemi destekleme" anlamındadır.

Kliktivizm ise, İngilizce'de tıklama anlamındaki "click" kelimesi ve 'aktivizm' kelimesinin birleştirilmesi ile oluşturulmuştur. Kavramın öncel kelimesi olan 'click', Türkçeye klik olarak çevrilebilmekte ve tıklamak, tık sesi çıkarmak anlamına gelmektedir. Kelime, bilgisayar faresi -mouse- ile yapılan tıklama eylemini ifade etmektedir. Kliktivizm kavramı Oxford İngilizce Sözlüğü'nde (2019), "politik ya da sosyal bir eylemi genellikle çok az bir çaba ve adanmışlık ile internet üzerinden sosyal medya ve çevirimiçi kampanyalar aracilığı ile destekleme pratĭği" olarak tanımlanmıştır.

Slaktivizm ya da kliktivizm, insanların dijital platformlarda bir şey yapmış olmak için pasif eylemlerde bulunmaklarını ve vicdanlarını rahatlatmaların ifade etmektedir (Turhan, 2017, s. 31). Her iki kavram da, insanların kendilerini rahatsız eden olay ya da durumlara yönelik olarak bir şeyler yapma tatmini yaşamalarını ve iyi hissetmelerini sağlamaktadır. Bu nedenle iki kavrama yönelik olarak 'pasif eylemcilik', miskin eylemciliği', 'tembel eylemciliği' ve 'koltuk eylemciliği' gibi nitelemeler de söz konusudur.

Taraf Olma/Savunuculuk Aktivizmi ve Hashtag Aktivizmi: 'Taraf olma aktivizmi' ya da 'savunuculuk aktivizmi' ile 'hashtag aktivizmi', dijital aktivizmin en bilinen türlerindendir. Her iki kavram birbiriyle benzeştiği ve zaman zaman birlikte uygulandığı için, bu çalışma kapsamında aynı kategoride ele alınmış ve açıklanmıştır.

Taraf olmak ya da savunuculuk -advocacy-, Oxford İngilizce Sözlügü’nde (2019); “belirli bir amaç veya harekete yönelik toplumsal destek veya öneri” ifadesiyle tanım bulmuştur. Taraf 
olmak ya da savunuculuk kavramı; herhangi bir hareket ya da düşünceyi söz, yazı ya da eylem ile doğru ve haklı göstermeye çalışmaktır. Obar ve arkadaşlarına (2016, s. 4) göre ise bu kavram; belirli bir bakış açısını veya durumu savunmak, desteklemek veya bu durum üzerine mücadele etmek kavramlarının daha ötesindeki bir anlam ifade etmektedir.

Genelde politik bağlamda kullanılan taraf olma/savunuculuk aktivizmi; birtakım hedefleri ilerletmeyi veya elde etmeyi amaçlayan, belirli aktörler tarafından gerçekleştirilen sistematik bir çabayı ifade etmektedir (Prakash ve Gugerty, 2010, s. 1). Ağların oluşturulması, sosyal aktörlerin kamusal alandaki rollerini hükümetlerin, kurumsal ve sosyal kuruluşların eylemlerine yönelik eleştirilerini dile getirmelerini ve politik ve sosyal sorunlara cevap vermeleri sürecinde savunuculuk etkinliğinde bulunmasını sağlayabilmektedir (Jansen, 2010, s. 39).

Hashtag aktivizmi, dijital aktivizmin bir diğer türüdür. Bu uygulama, aktivizme konu olan görüş ya da fikrin mikroblog ya da sosyal ağlarda başına hashtag işareti eklenmesi anlamına gelmektedir. Yang'a (2016, s. 13) göre dijital aktivizmde son yollarda yaşanan en ilginç gelişmelerden biri olan hashtag aktivizmi; söylemsel protesto amacıyla bir kelime, kalıp ya da cümlenin sosyal medyada etiketlenerek sunulmasıdır.

Hashtag kelimesi, 'hash' kelimesi ile 'tag' kelimesinden birleşmesinden oluşmaktadır. Hashtag kelimesinin kökeninde bulunan 'hash' kelimesi, Oxford İngilizce Sözlüğü’ne (2019) göre; "telefon, tuş takımı veya bilgisayar klavyesinde bir sembol olarak veya rakamdan önce kullanılan '\#' sembolüdür”. Oxford İngilizce Sözlüğü’nde (2019) "hashtag; sosyal medyada, web sitelerinde, uygulamalarda, özellikle de Twitter'da belirli bir konuyla ilgili mesajları tanımlamak için kullanılan işaret ile birlikte gelen bir kelime veya cümle" olarak tanımlanmıştır.

Hashtag oluşturmak; özellikle Twitter'da bilgi paylaşmanın ve harekete geçmenin etkili bir yoludur (Berridge vd. Portwood-Stacer, 2015, s. 342). Hashtag'ler, mesajları kategorileyerek belirli konulara dikkat çekilmesini sağlamaları nedeniyle oldukça etkilidirler. Aktivistler açısından hashtag'ler, etiketler aracılığıyla aynı ifadenin birden fazla kullanımını sağladığg gibi, başlangıçtaki diyaloğunun ötesinde ifade yaratımına da olanak tanımaktadır (Stache, 2014, s. 162).

Hacktivizm: 'Hacktivizm', diğer bir dijital aktivizm türüdür. Hacktivizm kavramı, İngilizce 'hack' kelimesi ve 'aktivizm' kelimesinin birleştirilmesi ile oluşturulmuştur. 'Hack' kelimesi, heklemek olarak Türkçeye çevrilebilmekte ve bilgisayar korsanlığı anlamına gelmektedir. Bu bağlamda 'hacktivist' kavramı, Oxford İngilizce Sözlüğü'nde (2019) “sosyal veya politik amaçlarını gerçekleştirmek için bilgisayar dosyalarına veya ağlara yetkisiz erişim sağlayan kişi”" olarak tanım bulmaktadır.

Hacktivizm; bilgisayar teknolojisinin veya programlama sistemlerinin toplumsal bir soruna yönelik tepki gösterme amaçlı kullanılmasıdır (Demirkıran, 2013, s. 28). Hacktivist eyleminin aktörü, 'hacker' olarak adlandırılmaktadır. Hacker, Oxford İngilizce Sözlüğü'nde (2019) "bilgisayarları verilere yetkisiz erişim sağlamak için kullanan kişi” olarak tanım bulmuştur. Kavram, Tükçe'de 'bilgisayar korsanı' olarak ifade edilmektedir. Türk Dil Kurumu Güncel Sözlüğü’nün (2019) tanımına göre bilgisayar korsanı, "Bilgisayar ve haberleşme teknolojileri 
konusundaki bilgisini gizli verilere ulaşmak, ağlar üzerinde yasal olmayan zarar verici işler yapmak için kullanan kimse” olarak tanımlanmıştır.

Hacktivizm, terminolojide tartışmaya açık bir terim olarak görülmektedir. Krapp (2003, s. 73); hacktivizm teriminin bir bakış açısına göre, programlama becerilerini eleştirel düşünme ile birleşerek elektronik temelli doğrudan eylemin toplumsal değişime etkilerini ifade ettiğini vurgulamaktadır. Bir diğer bakış açısı, hacktivizmin; internetin teknik, ekonomik ve politik bir platform olarak gizliliğini zayıflatan, yıkıcı eylemlerle eşanlamlı olduğuna dikkat çekmektedir. Dolayısıyla hacktivizm; dual bir anlama sahiptir ve hem iyicil, hem de kötücül olarak yorumlanmaktadır. Bununla birlikte dijital aktivizm kapsamında ele alındığında hacktivizm, olumlu bir kavram olarak değerlendirilmekte ve özellikle dişavurumcu politika, ifade özgürlüğü, insan hakları veya bilgi etiği ile ilişkilendirmektedir.

Info-aktivizm: Bir diğer dijital aktivizm türü olan 'info-aktivizm', enformasyon toplama ve enformasyon yayma şeklinde gerçekleştirilen aktivizmdir. Açılımı 'enformasyon aktivizmi' olan info-aktivizm, İngilizce 'information' kelimesi ile 'aktivizm' kelimelerinin birleştirilmesiyle oluşturulmuştur. $\mathrm{Bu}$ aktivizm türü, enformasyonun politik amaçlara topluluklara yayılması çabalarını ifade etmektedir. Diğer bir deyişle info-aktivizm, politik katılımın yeni bir formu olarak anlam bulmaktadır (Halupka, 2016).

İnfo-aktivizm, bilgi edinme hakkı üzerine temellenen bir aktivizm türüdür (Webb, 2013). İnfoaktivistlerin eylem tarzı, herhangi bir konuda sürecin önemli aktörlerini izlemek ve veri kümelerini değerlendirmek şeklindedir (Ganesh ve Hankey, 2015). İnfo-aktivizm, bilginin yayılımını esas almaktadır ve bilginin yayılımı dijital yollar üzerinden, aplikasyon desteği ile ya da online topluluklar aracılı̆̆ıyla gerçekleşebilmektedir (Lynch, 2014; McKinney, 2015, s. 9).

Maptivizm: Görece yeni bir dijital aktivizm türü olan 'maptivizm', lokasyon temelli aktivizm olarak ifade edilebilmektedir. Topluluk ile fiziksel olarak da bir arada olma ya da topluluk üyelerine belli konularda destek olma amacına hizmet eden maptivizm, üyelerin konum bilgisinden harekete geçen bir aktivizm türüdür. Kavram, İngilizce haritalama anlamına gelen 'mapping' kelimesi ile 'aktivizm' kelimesinin birleşmesi sonucu oluşturulmuştur. Maptivizm, sosyal-haritalama -social-mapping- kavramının yerine de kullanılmaktadır. Bu durum, maptivizmin sosyal niteliğine ve topluluğa dayalı yapısına işaret etmektedir (Ferguson vd. 2013, s. 308).

Maptivizm, fiziksel dünyanın ve sanal dünyanın birbiriyle etkileşimli bir şekilde aktivizm hareketine dahil olabileceğinin bir örneği olarak değerlendirilebilmektedir. Öyle ki konum bildirimi, kontrol ve gizlilik sorunu ile ilişkilendirilebilse de; teknolojinin aktivist hareketlerde lokasyon temelli kullanılması maptivizmi olumlayan bir nitelik arz etmektedir. Maptivizm ile aktivist kendi konumunu belirleme, bir alan sahibi olduğunu gösterme ve bunu hem sanal ortamda, hem de fiziksel ortamda uygulama avantajı kazanmaktadır (Campagna ve Boulds, 2018).

Maptivizm, belirli bir lokasyon dahilinde ortaya çıkan ve gelişen olaylara 1şık tutularak anlatı niteliği kazandırılmasına aracılık etmektedir. Maptivizm kapsamında kullanıcıların deneyimleri, yorumları ve algıları diğer kişilerle paylaşılabilmektedir. Bu sayede gerçek yaşamda da kullanıcılara yardımcı olabilecek bir 'anlatı' mekanizması oluşmuş olmaktadır 
(Kalms, 2019). Ek olarak maptivizmin sağladığı bilgi akışı ile aktivistler, enformasyon gücünü ellerine alarak güç dengesine yeni bir boyut katmaktadırlar (Ruiz, 2016, s. 66).

Aplikasyon Aktivizmi: 'Aplikasyon aktivizmi' ya da diğer bir ifadeyle - 'aptivizm-', diğer bir dijital aktivizm türüdür. Kavram, İngilizce 'application' kelimesi ile 'aktivizm' kelimesinin birleştirilmesi ile oluşturulmuştur. 'Application' kelimesi, Türkçeye uygulama olarak çevrilebilmekte ve kullanıcıların istedikleri işlemleri yapmalarını sağlayan yazılım olarak ifade edilebilmektedir.

Aplikasyon aktivizmi; aplikasyonlar, diğer bir ifadeyle uygulamalar aracilığıyla gerçekleştirilen aktivizm türü olarak tanımlanabilmektedir. Urban Dictionary'de (2019) aptivizm, "sosyal veya politik değişim gerçekleştirmek amacıyla yazılım -aplikasyonoluşturulması" olarak tanımlanmıştır. Barns (2014, s. 228) ise kavramı; veri güdümlü aktivizm -data-driven activism- kavramı ile birlikte kullanarak kavramın dijital veri ile ilişkisine dikkat çekmiştir.

Aplikasyon aktivizmi, günümüzün dijital dünyasında etkili bir araç olarak kabul görmektedir. Aplikasyonlar; bir işletim sisteminde çalışabilecekleri gibi, birden fazla platformda, diğer bir ifadeyle çoklu platformlarda çalışabilir ve kullanılabilir şekilde tasarlanmaktadırlar. Öyle ki yeni aplikasyonların internet sitelerinde, akıllı telefonlarda ve tabletlerde çalışabilmeleri ve kullanılabilmeleri, aplikasyon aktivizminin geniş bir uygulama alanına sahip olması sonucunu doğurmaktadır.

\section{Dijital Aktivizm Kavram ve Uygulamalarının Change.Org Örneğinde İncelenmesi}

\section{Amaç}

$\mathrm{Bu}$ çalışmanın amacı, dijital aktivizm kavram ve uygulamalarını Change.org kampanyaları üzerinden analiz etmek ve anlamaya çalışmaktır. Dijital aktivizm kavram ve uygulamalarına aracılık eden Change.org, 2007 yılında kurulan bir sosyal toplum girişimidir. 'Dünyanın değişim platformu' sloganını kullanmakta ve küresel çapta faaliyet göstermektedir. Change.org'un çalışma prensibi; insanlara, topluluklara ve kurumlara desteklenmesini istedikleri değişimle ilgili kampanya başlatmaları ve diğer insanların konuya yönelik desteklerini istemeleri için olanak tanımak ve bu hizmeti ücretsiz olarak sunmaktır. Açık platform esasına göre işleyen bu girişime, www.change.org adresi üzerinden ulaşılabilmektedir.

Dijital aktivizm kavram ve uygulamalarını, Change.org örneğinde analiz etmeye yönelik olan bu araştırmanın soruları, literatürden hareket ederek şu şekilde oluşturulmuştur:

- Türkiye'de dijital aktivizm hareketleri, hangi konular üzerinden şekillenmektedir?

- Türkiye'deki dijital hareketlerde hangi konulardaki aktivist kampanyalara destek görece yoğundur?

- Türkiye'de dijital aktivist hareketlerin başlatıcılarında kişi, kurum ve topluluklardan hangisi ön plandadır?

\section{Yöntem}

Araştırma, nitel yöntemle tasarlanmıştır ve betimsel niteliğe sahiptir. Araştırma evreni olarak Change.org kurumsal web sitesinde yer alan ve Türkiye'de 2018 yılında açılarak başarılı ulaşmış kampanyalar seçilmiştir. Araştırma evreninin seçiminde; Change.org'un dünyada ve 
Türkiye'de dijital aktivizm ile ilişkilendirilen bir platform olarak öne çıkması, literatürde yer alan dijital aktivizm kavram ve uygulamalarına koşut bir işleyişe sahip olması gibi unsurlar ağır basmıştır.

'Başarılı kampanya' nitelemesi, Change.org yetkililerinin ifadesiyle herhangi bir kampanyanın katılımcı sayısına bakılmaksızın amaçlanan sonuca ulaşması anlamına gelmektedir. Dijital aktivizm hareketlerinin kavram ve uygulama niteliğinin yanı sıra etki düzlemi açısından da incelemeye değer olması nedeniyle, araştırmanın Change.org platformunun 'başarılı' olarak nitelediği kampanyalar ile sınırlandırılmasına karar verilmiştir. Araştırma, Ocak 2018-Aralık2018 tarihlerini kapsamaktadır. Araştırma kapsamında, 2018 yılı verilerinin seçilme sebebi verilerin güncelliği ve dataların doygunluğudur.

\section{Bulguların Değerlendirilmesi}

Araştırma bulguları; 2018 yılına ait Change.org kampanyaları temel alınarak 'kampanya başlatıcısı', 'kampanya başlı̆̆ı', 'kampanya konusu', 'kampanya tarihi' ve 'kampanya destekçi sayısı' gibi kategoriler kapsamında derlenmiş ve yorumlanmıştır. Şubat 2019 tarihinde www.change.org adresinden derlenen söz konusu veriler, Tablo. 1.'de tarih sırasına göre dizilerek toplu olarak sunulmuştur.

Nitel araştırma -qualitative research-; kelimeler ya da gözlemler gibi ölçülmesi zor olan nitelikler üzerine odaklanan ve niteliklerin yorumlanmasına ve çözümlenmesine dayanan bir araştırma türüdür (Glesne, 2015, s. 385). Nitel araştırmanın bazı temel özelliklerinden söz etmek mümkündür. Nitel araştırma; 'anlam ve anlama üzerine odaklanma', 'doğal ortam', 'araştırmacı temelli bağlam', 'çoklu yöntemler', 'tümevarımsal mantık süreci', 'zamanla beliren desen', 'bütüncül açıklama' gibi belirleyici özelliklere sahiptir (Yıldırım ve Şimşek, 2013, ss. 54-71; Creswell, 2018, ss. 45-47; Meriam, 2018, ss. 14-19). Bu bağlamda betimsel nitelik arz eden bu çalışmada, Change.org kampanyaları tümevarımsal bir şekilde ele alınmış ve bulguların değerlendirilmesi aşamasında kampanya başlıklarından hareketle oluşturulan kategoriler kullanılmıştır.

Tablo 1. 2018 Yılında Açılan ve Başarıya Ulaşan Change.Org Kampanyaları'na İlişkin Veriler

\begin{tabular}{|c|c|c|c|c|}
\hline$\underline{\text { Kampanya Bașlatıcisı }}$ & Kampanya Bașlığ & $\frac{\text { Kampanya }}{\underline{\text { Konusu }}}$ & $\frac{\text { Kampanya }}{\underline{\text { Tarihi }}}$ & $\frac{\frac{\text { Kampanya }}{\text { Destekci }}}{\underline{\text { SayıSI }}}$ \\
\hline Kişi & $\begin{array}{l}\text { "İlahiyat Fakültesi Mezunlarının } \\
\text { İkinci Öncelikli Atanması } \\
\text { Konusunda Hak Olan Elbet Tecelli } \\
\text { Edecektir” }\end{array}$ & Eğitim & $\begin{array}{l}\text { Ocak } \\
2018\end{array}$ & 7.272 \\
\hline Kurum & $\begin{array}{l}\text { "Uluslararası Türk Dünyası } \\
\text { Çalıştayı Devam Etsin" }\end{array}$ & Kültür-Sanat & $\begin{array}{l}\text { Ocak } \\
2018\end{array}$ & 65 \\
\hline Kişi & $\begin{array}{c}\text { "Kurubük giderse, Datça da Gider. } \\
\text { Bırakın Kurubük Olduğu Gibi } \\
\text { Kalsın" }\end{array}$ & Çevre & $\begin{array}{l}\text { Ocak } \\
2018\end{array}$ & 8.836 \\
\hline Kişi & "2018 Bedelli Askerlik" & $\begin{array}{c}\text { Milli } \\
\text { Savunma }\end{array}$ & $\begin{array}{l}\text { Ocak } \\
2018\end{array}$ & 10 \\
\hline
\end{tabular}




\begin{tabular}{|c|c|c|c|c|}
\hline Kurum & $\begin{array}{l}\text { "HBV Taşıyıcısı Olmak Polis } \\
\text { Olmak İçin Engel Değildir" }\end{array}$ & Adalet & $\begin{array}{l}\text { Ocak } \\
2018\end{array}$ & 26 \\
\hline Kişi & $\begin{array}{l}\text { “Fenerbahçe Taraftarına } \\
\text { 'Yetiştirme' Diye Hitap Eden } \\
\text { Mahmut Uslu Derhal Özür } \\
\text { Dilesin" }\end{array}$ & Spor & $\begin{array}{l}\text { Şubat } \\
2018\end{array}$ & 6 \\
\hline Kişi & $\begin{array}{l}\text { "Bursaspor Voleybol ve Basketbol } \\
\text { Takımlarına Maaşları Ödensin Ve } \\
\text { De Başarı Primi Verilsin" }\end{array}$ & Spor & Şubat 2018 & 26 \\
\hline Topluluk & "DGS Sınavı Her İlde Yapılsın" & Eğitim & Şubat 2018 & 457 \\
\hline Kişi & $\begin{array}{l}\text { “Çeşme Devlet Hastanesi’nden } \\
\text { İsmi Çıkartılan Alper } \\
\text { Çizgenakat'ın İsmi Tekrar } \\
\text { Hastaneye Konulsun” }\end{array}$ & $\begin{array}{c}\text { Sivil } \\
\text { Toplum }\end{array}$ & $\begin{array}{l}\text { Mart } \\
2018\end{array}$ & 10.589 \\
\hline Kişi & $\begin{array}{l}\text { "Down Sendromlu Bireyler İçin } \\
\text { Meclis Göreve - } \\
\text { \#MeclisteDownSendromu } \\
\text { KomisyonuKurulsun" }\end{array}$ & Adalet & $\begin{array}{l}\text { Mart } \\
2018\end{array}$ & 93.438 \\
\hline Kişi & "Medresemiz Kapatılmasın" & $\begin{array}{c}\text { Yerel } \\
\text { Yönetim }\end{array}$ & $\begin{array}{l}\text { Mart } \\
2018\end{array}$ & 1.865 \\
\hline Topluluk & $\begin{array}{l}\text { "Köyümüzün Tarım Alanına } \\
\text { Santral İstemiyoruz" }\end{array}$ & Çevre & $\begin{array}{l}\text { Mart } \\
2018\end{array}$ & 501 \\
\hline Kişi & $\begin{array}{l}\text { "Sakarya Karasu Hürriyet } \\
\text { Mahallesinde Taş Ocağı } \\
\text { Açılmasın" }\end{array}$ & Çevre & $\begin{array}{l}\text { Mart } \\
2018\end{array}$ & 51 \\
\hline Kişi & $\begin{array}{c}\text { "Fıstıkağacı Durağı Eski Yerine } \\
\text { Taşınsın" }\end{array}$ & $\begin{array}{l}\text { Yerel } \\
\text { Yönetim }\end{array}$ & $\begin{array}{l}\text { Mart } \\
2018\end{array}$ & 501 \\
\hline Topluluk & $\begin{array}{c}\text { "Sokak Hayvanlarını Ölüme } \\
\text { Terk Etme Aydın Büyükşehir } \\
\text { Belediyesi” }\end{array}$ & $\begin{array}{l}\text { Hayvan } \\
\text { Hakları }\end{array}$ & $\begin{array}{l}\text { Mart } \\
2018\end{array}$ & 6.230 \\
\hline Kişi & $\begin{array}{c}\text { "Haksız Yere Görevinden Alınan } \\
\text { Polisimizin Görevine Dönmesini } \\
\text { İstiyoruz" }\end{array}$ & Adalet & Nisan 2018 & 45.792 \\
\hline Topluluk & $\begin{array}{l}\text { "Hepatit B ve Sağlıklı Taşıyıcılar } \\
\text { Polis ve Subay Olabilsin" }\end{array}$ & Adalet & Nisan 2018 & 1.586 \\
\hline Kişi & $\begin{array}{c}\text { "Sağlık Bakanlığı Opdivo Kanser } \\
\text { Hastaları İçin SSK Kapsamına } \\
\text { Alınsın" }\end{array}$ & Sağlık & Nisan 2018 & 730 \\
\hline Kişi & $\begin{array}{l}\text { "Çorum Faik Tonguç } \\
\text { Çocuk Kütüphanesi Yıkılmasın” }\end{array}$ & $\begin{array}{c}\text { Yerel } \\
\text { Yönetim }\end{array}$ & May1s 2018 & 23.316 \\
\hline Topluluk & $\begin{array}{c}\text { "Atatürk Havalimanı Central Park } \\
\text { Gibi Olmalı" }\end{array}$ & $\begin{array}{c}\text { Yerel } \\
\text { Yönetim }\end{array}$ & May1s 2018 & 78.481 \\
\hline Kişi & $\begin{array}{c}\text { "Erzincan'a D\&R açılmasını Talep } \\
\text { Ediyoruz" }\end{array}$ & $\begin{array}{c}\text { Yerel } \\
\text { Yönetim }\end{array}$ & May1s 2018 & 467 \\
\hline
\end{tabular}




\begin{tabular}{|c|c|c|c|c|}
\hline Kişi & $\begin{array}{c}\text { "17 B Hatt1 -Gebze-Kartal Metro- } \\
\text { Bir Önceki Güzergahına } \\
\text { Dönmesini Sağlayın" }\end{array}$ & $\begin{array}{l}\text { Yerel } \\
\text { Yönetim }\end{array}$ & May1s 2018 & 89 \\
\hline Kişi & “Zonguldak'a D\&R İstiyoruz" & $\begin{array}{l}\text { Tüketici } \\
\text { Hakları }\end{array}$ & $\begin{array}{c}\text { Mayis } \\
2018\end{array}$ & 231 \\
\hline Kişi & $\begin{array}{l}\text { “Köpeklerimizi Okulumuza Geri } \\
\text { İstiyoruz @UfukUni” }\end{array}$ & $\begin{array}{l}\text { Hayvan } \\
\text { Hakları }\end{array}$ & $\begin{array}{c}\text { Mayis } \\
2018\end{array}$ & 416 \\
\hline Kişi & $\begin{array}{c}\text { "PVL hastası Minik Kerem'in } \\
\text { Tedavisi İçin..." }\end{array}$ & Sağlık & $\begin{array}{l}\text { May1s } \\
2018\end{array}$ & 775 \\
\hline Kişi & $\begin{array}{c}\text { "Beyazıt Ford-Otosan İlkokulu’na } \\
\text { Başka Okul Gelmesin" }\end{array}$ & Eğitim & May1s 2018 & 248 \\
\hline Kişi & "Ezgi’ye Protez Bacak" & Sağlık & $\begin{array}{l}\text { Haziran } \\
2018\end{array}$ & 109 \\
\hline Kişi & $\begin{array}{l}\text { "Diyetisyenlerin Mesleğine } \\
\text { Karışmayın. MEB Onaylı } \\
\text { Sertifikalı Beslenme Eğitimine } \\
\text { İtiraz Et" }\end{array}$ & Sağlık & $\begin{array}{l}\text { Haziran } \\
2018\end{array}$ & 3.555 \\
\hline Kişi & $\begin{array}{l}\text { “Adalet Bakanlığı: } \\
\text { Türkçe Rap'in Parlayan Yıldızı } \\
\text { Ezhel Serbest Bırakılsın" }\end{array}$ & Adalet & $\begin{array}{c}\text { Haziran } \\
2018\end{array}$ & 24.459 \\
\hline Kişi & $\begin{array}{c}\text { “Türkçe Rap'in Parlayan Yıldızı } \\
\text { Ezhel Serbest Bırakılsın - } \\
\text { \#FreeEzhel” }\end{array}$ & Adalet & $\begin{array}{l}\text { Haziran } \\
2018\end{array}$ & 162.907 \\
\hline Kişi & $\begin{array}{l}\text { “Kaputaş’a Viyadük Yaptırma - } \\
\text { \#KaputaşaViyadükYaptırma”" }\end{array}$ & Çevre & $\begin{array}{l}\text { Haziran } \\
2018\end{array}$ & 17.588 \\
\hline Kişi & $\begin{array}{c}\text { “Kültür ve Turizm Bakanlığı: } \\
\text { Salda Festivali -Saldafest” İptal } \\
\text { Edilsin” }\end{array}$ & Çevre & $\begin{array}{c}\text { Haziran } \\
2018\end{array}$ & 188 \\
\hline Kişi & $\begin{array}{c}\text { “\#FakültemeDokunma İstanbul } \\
\text { Tıp Fakültesi Tarihinden } \\
\text { Koparılmasın” }\end{array}$ & Adalet & $\begin{array}{c}\text { Haziran } \\
2018\end{array}$ & 26.395 \\
\hline Kişi & $\begin{array}{c}\text { "İstanbul Devlet Konservatuvarı } \\
\text { Binamıza Dokunma" }\end{array}$ & Adalet & $\begin{array}{l}\text { Temmuz } \\
2018\end{array}$ & 163.361 \\
\hline Kişi & $\begin{array}{l}\text { "Yavru Aslanı 'Mevzoo' Cafe'den } \\
\text { Kurtaralım” }\end{array}$ & $\begin{array}{l}\text { Hayvan } \\
\text { Hakları }\end{array}$ & $\begin{array}{l}\text { Temmuz } \\
2018\end{array}$ & 5.760 \\
\hline Kişi & $\begin{array}{c}\text { "Ebru Özkan'ın Kurtarılmasına } \\
\text { Yardım Et" }\end{array}$ & Adalet & $\begin{array}{c}\text { Temmuz } \\
2018\end{array}$ & 18.704 \\
\hline Kişi & $\begin{array}{l}\text { “Atatürk'e Anıtkabir'de Hakaret } \\
\text { Eden Kişi Tutuklansın” }\end{array}$ & Adalet & $\begin{array}{c}\text { Temmuz } \\
2018\end{array}$ & 2.079 \\
\hline Kişi & $\begin{array}{c}\text { "McDonalds'in Artık Düzce'de De } \\
\text { Evlere Sipariș Hizmeti Vermesini } \\
\text { İstiyoruz" }\end{array}$ & $\begin{array}{l}\text { Tüketici } \\
\text { Hakları }\end{array}$ & $\begin{array}{c}\text { Temmuz } \\
2018\end{array}$ & 18 \\
\hline Kişi & $\begin{array}{l}\text { “Hukuk Bölümü Baraj1 } \\
\text { Düşürülsün" }\end{array}$ & Eğitim & $\begin{array}{l}\text { Ağustos } \\
2018\end{array}$ & 33 \\
\hline
\end{tabular}




\begin{tabular}{|c|c|c|c|c|}
\hline Topluluk & $\begin{array}{l}\text { "Ankara Üniversitesi Bütünleme } \\
\text { Sinavlarını Geri İstiyor" }\end{array}$ & Eğitim & $\begin{array}{l}\text { Ağustos } \\
2018\end{array}$ & 1.592 \\
\hline Kişi & $\begin{array}{l}\text { "Dr. Özlem Yağdıran Görevine } \\
\text { İade Edilsin" }\end{array}$ & Adalet & $\begin{array}{l}\text { Ağustos } \\
2018\end{array}$ & 956 \\
\hline Kişi & $\begin{array}{l}\text { "Halıdere'de Taş Ocağı } \\
\text { Kapatılsın" }\end{array}$ & Çevre & $\begin{array}{l}\text { Ağustos } \\
2018\end{array}$ & 389 \\
\hline Kişi & $\begin{array}{c}\text { "Dünyadaki İlk Atatürk Heykeline } \\
\text { Özgürlüğ̈ünü Geri Verin” }\end{array}$ & $\begin{array}{c}\text { Yerel } \\
\text { Yönetim }\end{array}$ & Eylül 2018 & 27.621 \\
\hline Kişi & $\begin{array}{l}\text { “Sözleşmeli Öğretmenlere Eş } \\
\text { Durumu Tayini Hakkı İstiyoruz" }\end{array}$ & Adalet & Eylül 2018 & 113 \\
\hline Kişi & $\begin{array}{l}\text { "KYK Yurt Ücretlerine Yapılan } \\
\text { Zamlar Geri Çekilsin" }\end{array}$ & Eğitim & Eylül 2018 & 43 \\
\hline Kişi & $\begin{array}{l}\text { “Komşufirın’larda Satılamayan } \\
\text { Ürünler Akşam Çöpe Gitmesin - } \\
\text { @komsufirinda” }\end{array}$ & $\begin{array}{l}\text { Tüketici } \\
\text { Hakları }\end{array}$ & Eylül 2018 & 7.092 \\
\hline Kişi & $\begin{array}{c}\text { “KYK Öğrencileri İlk Ders } \\
\text { Gününde Yurda Yerleşme } \\
\text { Mağduru Olması"” }\end{array}$ & Eğitim & Eylül 2018 & 797 \\
\hline Kişi & $\begin{array}{l}\text { KYK Yurtları } 24 \text { Eylülden Daha } \\
\text { Erken Bir Tarihte Açılsın" }\end{array}$ & Eğitim & Eylül 2018 & 651 \\
\hline Kişi & $\begin{array}{c}\text { "Yağmur Babasına Verilsin İcra } \\
\text { Memurlarıyla Zorla Alınan } \\
\text { Yağmur Ben Mal Mıyım Diye } \\
\text { Ağladı" }\end{array}$ & Adalet & Eylül 2018 & 33 \\
\hline Kişi & "KYK Yurtları Erken Açılsın" & Eğitim & Eylül 2018 & 184 \\
\hline Kişi & $\begin{array}{l}\text { "Anı Tur Aracıllğıyla Yapılan } \\
\text { Rezervasyonların İptali Hakkında" }\end{array}$ & $\begin{array}{l}\text { Tüketici } \\
\text { Hakları }\end{array}$ & Eylül 2018 & 63 \\
\hline Kişi & $\begin{array}{l}\text { "Urla Devlet Hastanesi'ne Acil } \\
\text { Çocuk Servisi Açılsın" }\end{array}$ & Sağlık & Eylül 2018 & 77.192 \\
\hline Kişi & $\begin{array}{l}\text { "Ankara Çankaya Belediyesi } \\
\text { Engellilere Ayrımcılık Yapma" }\end{array}$ & Adalet & Eylül 2018 & 19.464 \\
\hline Kişi & $\begin{array}{c}\text { "Anasınıfına Kayıt Parası Yok } \\
\text { Diye Alınmayan Minik Yavruya } \\
\text { Ses Oluyoruz" }\end{array}$ & Eğitim & Ekim 2018 & 50 \\
\hline Kişi & $\begin{array}{c}\text { “Algida'dan Glutensiz Dondurma } \\
\text { İstiyoruz" }\end{array}$ & $\begin{array}{l}\text { Tüketici } \\
\text { Hakları }\end{array}$ & Kasım 2018 & 4.431 \\
\hline Kurum & $\begin{array}{l}\text { “Zeugma'dan Amerika'ya } \\
\text { Kaçırılan Mozaikler İade edilsin” }\end{array}$ & Kültür-Sanat & Kasım 2018 & 44.186 \\
\hline Kişi & $\begin{array}{l}\text { "Eşim Fatoş Kızımızın } \\
\text { Anne Dediğini Duysun - } \\
\text { \#fatoşeylülüduysun" }\end{array}$ & Sağlık & Kasım 2018 & 102.189 \\
\hline Kişi & $\begin{array}{l}\text { "Isparta Dedegöl Dağları } \\
\text { Kuzukulağ1 Yaylası Korunan Alan } \\
\text { İlan Edilsin" }\end{array}$ & Çevre & Kasım 2018 & 11.041 \\
\hline
\end{tabular}




\begin{tabular}{|c|c|c|c|c|}
\hline Kişi & $\begin{array}{l}\text { "Türkiye'de Plastik Poşet } \\
\text { Kullanımı Paralı Olsun" }\end{array}$ & Çevre & Aralık 2018 & 906 \\
\hline Kişi & $\begin{array}{l}\text { "Plastik Poşetler Paralı Olmalı, } \\
\text { Çevremizi Korumalıyı" }\end{array}$ & Çevre & Aralık 2018 & 4.592 \\
\hline Kişi & $\begin{array}{l}\text { “+1 Destek Çok Zor Değil - } \\
\text { \#İyilikAtölyesiKapanmasın” }\end{array}$ & Sivil Toplum & Aralık 2018 & 51.863 \\
\hline Kişi & $\begin{array}{l}\text { "Evlat Edinme Başurusu } \\
\text { Onaylanmış Adayların } 40 \text { Yaş } \\
\text { Sınırı Kaldırılsın" }\end{array}$ & Adalet & Aralık 2018 & 1.476 \\
\hline Kişi & $\begin{array}{llr}\text { "Fenerbahçemiz } & \text { İçin } \\
\text { \#YenidenErsun Yanal } & - \\
\text { \#TamZamanıErsunYanal" } & \end{array}$ & Spor & Aralık 2018 & 85.530 \\
\hline Kişi & “Asgari Ücret 2000 TL Olsun” & Adalet & Aralık 2018 & 50.552 \\
\hline Kişi & $\begin{array}{l}\text { "Yasonburnu } \\
\text { Dokunmayın" }\end{array}$ & Çevre & Aralık 2018 & 36.493 \\
\hline
\end{tabular}

Kaynak: https://www .change.org/tr/başardıklarınız\#most-recent adresinden 02.02.2019 tarihinde derlenerek tablolaştırılmıştır.

Araştırma kapsamında, Change.Org platformunda 2018 yılı dahilinde Türkiye'de yürütülen ve başarıya ulaşan altmış beş adet kampanya tespit edilmiştir. Bulgular, 'kampanya başlatıcısı' kategorisi üzerinden ele alındığında; 'kişi', 'topluluk' ve 'kurum' olmak üzere üç alt kategori tespit edilmiştir. Bu bağlamda 2018 yılında başarıya ulaşan Change.org kampanyalarının başlatıcıları, büyük oranda kişidir. Sayısal orana göz atıldığında başarıya ulaşmış altmış beş kampanyanın, elli altı tanesi kişiler tarafından başlatılmıştır. Söz konusu kampanyaların altı tanesinin başlatıcısı topluluk, üç tanesinin ise kurumdur.

Kampanya başlatıcılarına ilişkin bu bulgu, diijital aktivizmin bireysel niteliğine vurgu yapmaktadır. Öyle ki dijital aktivizm, bireyin ve küçük grupların eylemliliğini, eylemci kimliğini tanımlayan ve güçlendiren bir deneyim olarak hayatımıza girmiştir (Çoban ve İnceoğlu, 2015, s. 14). Araştırma bulguları da, dijital aktivizmin bireyselliğin ön planda olduğu ve örgütlü bir yapıya sahip olmadı̆̆ gerçeğine uyumludur.

Araştırma bulguları 'kampanya başı̆̆ğı' kategorisi üzerinden ele alındığında, 2018 yılında başarıya ulaşmış Change.org kampanyalarının geniş bir konu zenginliğine sahip olduğu saptanmıştır. Bu durum da, literatür taramasında elde edilen bulgularla tutarlılık içindedir. Aktivizm, 1970'lerden itibaren konu açısından genişleyen bir çehreye sahiptir. Dijital aktivizm, aktivizmin konu yelpazesinin daha da zenginleşmesini sağlamıştır.

Bulgular uyarınca 2018 yılında Change.org platformu aracılığıyla başarıya ulaşan kampanyaları, on bir ayrı konu üzerinden sınıflandırmak mümkündür. 'Adalet' , 'eğitim' 'çevre' 'yerel yönetim', 'sağlık', 'tüketici hakları', 'hayvan hakları', 'spor', 'sivil toplum', 'kültürsanat' ve 'milli savunma' söz konusu konulardır.

Sayısal orana bakıldığında, konu kategorisinde en dikkat çeken temanın 'adalet' olduğu görülebilmektedir. Change.org platformunda, 2018 yılı kapsamında adalet ile ilgili on altı başarıyla ulaşan kampanya bulunmaktadır. Bu bağlamda Change.org mikro örneğini, Türkiye'deki hak ve hukuk arayışına ilişkin bir gösterge olarak yorumlamak mümkündür. 
Adalet temasını, on kampanya ile 'eğitim' ve 'çevre' takip etmektedir. Eğitim ve çevrenin, yakın dönemde Türkiye'nin en çok konuştuğu konular olması bu bulgu ile örtüşmektedir.

Eğitim ve çevre konularını, yedi kampanya ile yerel yönetim takip etmektedir. Yerel yönetimlerin, ülke yönetimindeki ve yerel kalkınmadaki önemi düşünüldüğünde, bu oranın yüksekliği şaşırtıcı değildir. Tüketici hakları, dikkat çeken bir diğer temadır. Bu bulgu uyarınca küreselleşen kapitalist dünyada, tüketicilerin markalarla iletişim kurma ve beklentilerinin onlar tarafından yanıtlanması arzusunda olduklarını düşünmek mümkündür.

Hayvan hakları ve spor, 2018 yılı kapsamında üçer kampanya ile karşılık bulmuştur. Her iki konunun da birey ve toplum nezdindeki önemi, Change.org platformunda da yer bulmuş olmalarını sağlamıştır. Özellikle hayvanlarla ilgili Türkiye'de yakın dönemde yaşanan olumsuzluklar nedeniyle, hayvan hakları ile ilgili üç kampanyanın da yüksek oranda destekçi bulması ve başarıyla ulaşması memnuniyet vericidir. Sporla ilgili bir kampanya ise, Aralık 2018'de başlatılmıştır ve Fenerbahçe ile ilgilidir. Bu bağlamda futbolun Türkiye' de ve dünyada kitlelerin yoğun ilgisini çeken bir spor dalı olduğu bilinen bir gerçektir.

Kampanyaların sayısal dağılımında kültür-sanat konusuna ait iki kampanya, milli savunma konusuna ait bir kampanya bulunmaktadır. Kültür-sanat konularının azlığı, Türk toplumunun bu konularına ilişkin tepkiselliğinin düşük olduğu şeklinde değerlendirilebilmektedir.

Kampanya başlıkları söylemleri açısından değerlendirildiğinde, araştırma evrenine dahil olan Change.org kampanyalarının kampanya konusuna ilişkin istemi 'tekil' ve 'çoğul', diğer bir ifade ile 'Ben' dili ve 'Biz' dili ile dile getirdikleri saptanmıştır. Bununla birlikte kampanya başlıklarının dili sayısal olarak incelendiğinde çoğul ifade içerdikleri ve 'Biz' diliyle tasarlandıkları bulgulanmıştır. Söz konusu bulgu, kampanya başlatıcısının kişi, topluluk ya da kurum olmasından muaftır. Change.org, kampanya başlatıcılarına tekil ya da çoğul bir söylemle kampanya başlığı oluşturma olană̆ı vermiştir. Dolayısıyla bu durum, kampanya başlatıcılarının tercihlerini yansıtmaktadır. Bu paralelde bazı kampanya başlıkları uzun ve detaylı, bazı kampanyalar kısa ve net bir şekilde tasarlanmıştır. Bazı başlıklar ise, hashtag içerecek şekilde düzenlenmiştir. Bu durum da, platformun kampanya başlatıcılarına tanıdığı özerklik ve kampanya başlatıcılarının tasarrufları ile ilgilidir.

2018 yılında yürütülmüş ve başarıya ulaşmış Change.org kampanyaları, tarih temelinde ele alındığında; en yüksek oranın on bir kampanya ile eylül ayına ait olduğu görülmektedir. Eylül ayında açıların kampanyalara göz atıldığında ise, en dikkat çeken temanın dört kampanya ile eğitim olduğu saptanmıştır. Okulların eylül ayında okulların açılması nedeniyle kampanya başlatıcısı ve destekçilerin olası bir sorunu çözmek amacıyla kampanya başlatıkları yorumu yapılabilmektedir. Eğitim temasını, üç kampanya ile adalet teması izlemektedir ki adli tatil sonrası hukuka ilişkin arayışların da vuku bulduğu düşünülebilmektedir. Eylül ayında bahsi geçen kampanyaların yanı sıra tüketici hakları ile ilgili iki, yerel yönetim ile ilgili bir ve sağlık ile ilgili bir kampanya açılmıştır.

2018 yılında mayıs ayında sekiz; mart, haziran ve aralık aylarında yedi kampanya açılmıştır. Yılın ilk ayı olan ocak ayında, beş kampanya açılmıştır. Ocak ayını yine beş kampanya ile temmuz, dört kampanya ile ağustos ve kasım, üç kampanya ile şubat ayı izlemektedir. Bir kampanya ile ekim ayı, yılın en az aktif olan ayıdır. 
Kampanyaların mevsimsel dağılımına göz atıldığında, on sekiz kampanya ile ilkbahar en yüksek orana sahip mevsimdir. Sonbahar ve yaz aylarında on altı, kış aylarında on beş kampanya açılmış ve başarıya ulaşmıştır. Bu bağlamda Change.org kampanyalarının yılın tüm mevsimlerinde aktif olduğunu ifade etmek mümkündür. 2018 yılı kapsamındaki başarıyla ulaşmış altmış beş kampanya, ay bazında değerlendirildiğinde, ortalama olarak ayda beş kampanyanın ses getirdiği yorumu yapılabilmektedir ki bu, aslında kamuoyu sesi adına oldukça yüksek bir orandır.

2018 yılında yürütülmüş ve başarıya ulaşmış Change.org kampanyaları, destekçi sayısı açısından değerlendirildiğinde en yüksek destekçi sayısına sahip kampanyanın 163.36 kişi tarafından desteklendiği, en düşük destekçi sayısına sahip kampanyanın ise altı kişi tarafından desteklendiği görülebilmektedir. Bu bağlamda en yüksek destekçi sayısına sahip kampanya temmuz ayına aittir ve adalet temalıdır. En düşük destekçi sayısına sahip kampanya ise şubat ayına aittir ve spor ile ilgilidir.

Kampanya destekçi sayıları, belirli referans aralıkları temel alınarak incelendiğinde, 1-99 kişi aralığında desteklenen on üç kampanyanın, 100-999 kişi aralığında desteklenen on sekiz kampanyanın, 1.000-9.999 kişi aralığında desteklenen on üç, 10.000-99.999 kişi aralığında desteklenen on sekiz, 100.000-200.000 kişi aralığında desteklenen üç kampanyanın bulunduğu saptanmiştır.

En yüksek destekçi sayısına sahip kampanyalar mercek altına alındığında, üç kampanyanın da ortak bir temaya sahip oldukları görülmektedir. Temmuz, haziran ve mart ayları ile tarihlenen üç kampanya da, adalet temalıdır. Adalet arayışına yönelik olan söz konusu kampanyalara olan yoğun katılımın, Türk toplumunun konuya yönelik beklentisine işaret ettiği yorumunu yapmak mümkündür.

\section{Sonuç}

İletişim teknolojilerinde yaşanan gelişmeler ve internetin tüm yaşam alanlarını kapsayacak şekilde yaygınlaşması, aktivizm hareketlerini de dönüştürmüş̧ür. Yeni dönemin aktivizm anlayışı, 'dijital aktivizm' olarak adlandırılmaktadır. 1998 yılında kurulan MoveOn.org ve Care2 gibi platformlar, 1999 yılında yaşanan Seattle eylemleri, 2000 yılında kurulan GoPetition ile 2007 yılında kurulan Change.og ve Avaaz.org gibi platformlar, 2010 yılında başlayan Arap Baharı olarak adlandırılan halk hareketleri dijital aktivizm kavram ve uygumalarının kilometre taşlarını oluşturmaktadır.

Dijital aktivizm; insanın daha iyi, daha güzel, daha eşit bir dünya umudunun çağcıl dünyaya özgü halidir ve dijital ağlar üzerinden eyleme dökülmektedir. Bu çalışmada dijital aktivizm kavramı, Change.org üzerinden mercek altına alınmıştır. Change.org, dijital aktivizmin küresel çapta yaygınlaşması açısından oldukça önemli bir girişimdir. Araştırmanın verileri, 2018 yılını içermektedir. Bu bağlamda araştırmanın kısıtını, dijital aktivizme ilişkin diğer platformlar ve 2018 haricinde Change.org platformunda elde edilebilecek olan veriler oluşturmaktadır.

Araştırmada elde edilen bulgular, literatür taramasına koşutluk arz etmektedir. Bu bağlamda literatür bilgileri ve araştırma bulguları dijital aktivizm tanımı, dijital aktivizm konuları, dijital aktivizm türleri, dijital aktivizmin birçok mecranın birlikte kullanımına olanak veren çoklu niteliği gibi konular temelinde benzeşmektedir. 
Araştırma bulgularının genel değerlendirilmesinde en dikkat çeken veri, kampanya başlatıcıları ile ilgilidir. Araştırma kapsamında Change.org platformundaki dijital aktivizm kampanyalarının başlatıcılarının büyük oranda, kişi oldukları görülmüştür. Bu durum dijital aktivizmin, yeni iletişim teknolojileri ve internet aracılığıyla sıradan insanın eylemciye dönüşümüne aracılık eden niteliğine gönderme yapmaktadır.

Araştırma bulgularından elde edilen bir diğer önemli veri, Change.org platformu aracılı̆̆ıyla başlatılan kampanyaların geniş konu dağılımları ile ilgilidir. Kampanyalar adalet, eğitim, çevre, yerel yönetim, sağlık ve tüketici hakları gibi geniş bir konu yelpazesine sahiptir. Konuların bir diğer dikkat çekici niteliği, toplumsal hassasiyete yönelik olmalarıdır. Bu paralelde Change.org kampanyalarının, yakın dönem kamu gündemine uygunluk gösterdiğini ifade etmek mümkündür. Çevre ile ilgili iki kampanya, yakın dönem kamu gündemi açısından özellikle önemlidir. Aralık 2018 ile tarihlenen söz konusu kampanyalar, plastik poşet kullanımının ücretli olması ile ilgilidir. Kampanya başlatıcıları kişi olan her iki kampanya, çevre temasını konu etmekte ve çevrenin korunması isteminden hareket etmektedir. Çevre ve Şehircilik Bakanlığı Atık Yönetmeliği kapsamında 01.01.2019 tarihinden itibaren tüm Türkiye'de ücretli poşet uygulamasının başlatılması, bu kampanyaların başarılarına ilişkin kanıt olarak değerlendirilebilmektedir.

Araştırma bulgularından elde edilen bir diğer önemli veri, kampanya başlıklarının tasarlanışı ile ilgilidir. Change.org, kampanya başlatıcılarına kampanyaları ile ilgili arzu ettikleri gibi tasarlayabilme şansını veren bir yapıya sahiptir. Öyle ki kampanya başlatıcıları, Change.org'un kendilerine tanıdığı özerklik kapsamında kampanya başlıklarını tekil ya da çoğul söylem kullanarak ve diledikleri oranda bilgi ile donatarak tasarlayabilmişlerdir.

Kampanya başlıkları söylem açısından değerlendirildiğinde, 'Biz' dili ve 'Ben' dili kullanan başlıkların yanı sıra kampanya hakkında uzun ve detaylı bilgi ya da kısa ve net bilgi içeren başlıklar bulgulanmıştır. Dolayısıyla araştırma kapsamında kampanya başlatıcısının kendisini kampanya katılımcıları ile birlikte bir bütün kabul ederek muhatabına seslendiği başlıklara rastlamak mümkün olmuştur. Kampanya başlıkları içerdikleri bilgiler açısından ele alındığında ise; sorunu dile getiren, çözüm öneren, harekete sevk eden, durumu ideal olanla kıyaslayan başlıklara rastlamak mümkün olmuştur. Araştırma başlıkları ile ilgili dikkat çeken bir diğer nokta, hashtag içeren ve '@' işareti kullanarak doğrudan muhataba yönelik tasarlanan başlıkların varlığıdır. Bu başlıklar, dijital aktivizmin birden fazla mecrayı birleştiren çoklu niteliğine yönelik ipuçları olarak değerlendirilebilmektedir.

Araştırma bulgularına ilişkin bir diğer veri; kampanyaların kampanya başlatıcılarının bireysel ilgi alanlarına yönelik olarak tasarlanmış olmasıdır. Diğer bir deyişle söz konusu kampanyalar, kampanya başlatıcılarının öznel eylem ve etki alanları ile sınırlıdır. Bu durum, eski aktivizm anlayışı ile yeni aktivizm anlayışı arasındaki odak ve kapsam farklılığı ile açıklanabilmektedir. Literatürde konu edildiği üzere eski aktivizm anlayışı; büyük toplumsal sorunlara odaklanmakta, toplumsal sorunları ele alış ve çözüş tarzı ile makro bir nitelik arz etmektedir. Yeni aktivizm anlayışı ise, daha bireysel niteliktedir ve bireylerin sorun arz ettiğini düşündükleri konulara yönelik tasarlanmaktadır. Dolayısıyla sorunları ele alış ve çözüş tarzı açısından mikro bir nitelik arz etmekte, kitleler üzerinde sarsıcı etkiler yaratmamaktadır.

Tüm bu bulgular ve varılan sonuçlar doğrultusunda, ileriki çalışma ve araştırmalara yönelik aşağıdaki öneriler sunulmuştur: 
- Dijital aktivizmin toplumsal sorunlara yönelik -cinsiyet ayrımcılığı, pedofili, ırkçılık, ekoloji, hayvan hakları vb.- yönelik uygulamalarını mercek altına alan ve kültürlerarası kıyaslamalar yapan araştırmalar gerçekleştirilebilir.

- Dijtital aktivizm gelişmekte olan bir kavram ve uygulama alanıdır. İletişim teknolojilerindeki gelişmelere koşut olarak farklı şekillerde uygulanabilmesi mümkün olabilecektir. Bu nedenle dijital aktivizmin gelecekteki görünümüne odaklanan çalışmalar gerçekleştirilebilir.

- Bu araştırmanın verileri, Change.org platformunda yer alan ve Türkiye'de 2018 yılı kapsamında açılarak başarılı olmuş araştırmalar ile sınırlıdır. Söz konusu platformda açılan ve farklı zaman aralıklarını içeren araştırmalar gerçekleştirilebilir.

- Change.org kampanyalarını konu alan bu ve benzeri araştırmalar üzerinden farklı örneklem grubu, farklı araştırma deseni, farklı yöntem seçilerek farklı kurgulanmış araştırmalar gerçekleştirilebilir.

- Change.org platformunu mercek altına alan ve kampanyaların etkinlik yönetimi sürecini konu eden araştırmalar gerçekleştirilebilir.

\section{Kaynakça}

Akarsu, B. (1975). Felsefe Terimleri Sözlü̆̆̈̈̈. Ankara: Türk Dil Kurumu.

Barns, S. (2014). Plus ÇA Change? Remaking the City, 'One Site, One App, One Click at A Time'. City, 18(2), 226-229.

Benkler, Y. (2006). The Wealth of Networks. New Haven: Yale University.

Berridge, S. \& Portwood-Stacer, L. (2015). Feminism, Hashtags and Violence Against Women And Girls. Feminist Media Studies, 15(2), 341-358.

Bilgin, N. (2014) Sosyal Bilimlerde İçerik Analizi Teknikler ve Örnek Çalışmalar, Ankara: Siyasal Kitabevi.

Campagna, T. \& Boulds, L. (2018). Grassroots Maptivism: Mapping Feminist Movements Around the World. Masters of Media-New Media\&Digital Culture M.A., University of Amsterdam. https://mastersofmedia.hum.uva.nl/blog/2018/ 10/23/52155/. Erişim Tarihi: 05.03.2019.

Camus, A. (1997). Sisifos Söyleni. Çeviren: Tahsin Yücel. İstanbul: Can.

Christensen, H. S. (2011). Political Activities on The Internet: Slactivism or Political Participation by Other Means? First Monday, 16, 2-7.

Cresswell, J. W. (2018). Nitel Araştırma Yöntemleri. 4. Bask1. Çeviri Editörü: Mesut Bütün \& Selçuk Beşir Demir. Ankara: Siyasal Kitabevi.

Çoban, S. \& İnceoğlu, Y. (2015). Internet ve Sokak. İstanbul: Ayrıntı.

Demirkıran, P. (2013). Hacktivism. A. Keleş ve Y. Sal (Eds.). Hack Kültürü̈ ve Hacktivizm içinde (s. 27-33). İstanbul: Alternatif Bilişim Derneği.

Ferguson, J. Soekijad, M. Huysman, M. Vaast H. (2013). Blogging for ICT4D: Reflecting and Engaging with Peers to Build Development Discourse. Info Systems Journal, 23, $307-$ 328.

Halupka, M. (2016). The Rise Of Information Activism: How To Bridge Dualisms And Reconceptualise Political Participation. Information, Communication \& Society, 19(10). 
Hançerlioğlu, O. (1994). Felsefe Sözlü̆̆̈̈. İstanbul: Remzi Kitabevi.

Ganesh, M. I. \& Hankey, S. (2015). From İnformation Activism To The Politics Of Data. The Fibreculture Journal 26, 275-286.

Glesne, C. (2015). Nitel Araştırmaya Giriş. 5. Bask1. Çeviri Editörü: Ali Ersoy \& Pelin Yalçınoğlu. Ankara: Anı..

Giddens, A. (2000). Sosyoloji. Çeviren: Hüseyin Özel vd. Ankara: Ayraç.

Gürel, E. \& Muter Şengül, C. (2013). Ludizm. Ç. Bulut ve İ. Pırnar (Eds.). Uluslararası Işletmecilik: Temel Kavramlar. (s. 311-326), Ankara: Nobel.

Jenkins, H. (2016). Youth Voice, Media, And Political Engagement: Introducing the Core Concepts. H. Jenkins et al. (Eds.). By Any Media Necessary- The New Youth Activism, içinde. New York: New York University.

Joyce, M. (2010). Introduction: How to Think About Digital Activism. M. Joyce (Ed.). Digital Activism Decoded: The New Mechanics of Change içinde. New York: International Debate Education Association.

Kalms, N. (2013). Urban Exposure: Feminist Crowd-Mapping and The New Urban Imaginary. C. Lindler \& M. Meissner (Ed.). The Routledge Companion to Urban Imaginaries içinde (s. 159-170). New York: Routledge.

Karagöz, K. (2013). Yeni Medya Çağında Dönüşen Toplumsal Hareketler Ve Dijital Aktivizm Hareketleri. Iletişim ve Diplomasi, 1, 131-157.

Krapp, P. (2003). Terror and Play, Or What Was Hacktivism? Grey Room, 21, 70-93.

Laer, J. V. \& Aelst, P. V. (2010). Internet and Social Movement Action Repertoires. Information, Communication\&Society, 13(8),1146-1171.

Lynch, L. (2014). “Oh, WikiLeaks, I Would So Love to RT you:” WikiLeaks, Twitter, and Information Activism, International Journal of Communication,8, 2679-2692.

McKinney, C. J. (2015). Feminist Information Activism: Newsletters, Index Cards and the 21stCentury Archive. Unpublished Doctoral Dissertation. Communication and Culture Program. Toronto: York University.

Merriam, Sharan B. (2018). Nitel Araştırma-Desen ve Uygulama İçin Bir Rehber. 3. Bask1. Çeviri Editörü: Selahattin Turan. Ankara: Nobel.

Morozov, E. (2010). Think Again: The Internet. Foreign Policy. https://foreignpolicy.com/2010/04/26/think-again-the-internet/ Erişim Tarihi: 03.01.2019.

Obar, J. A. et al. (2012). Advocacy 2.0: An Analysis of How Advocacy Groups in The United States Perceive and Use Social Media As Tools For Facilitating Civic Engagement And Collective Action. Journal of Information Policy, 2, 1-25.

Oxford English Dictionary (2019). https://en.oxforddictionaries.com/definition/advocacy. Erişim Tarihi: 08.02.2019.

Oxford English Dictionary (2019). https://en.oxforddictionaries.com/definition/clicktivism. Erişim Tarihi: 08.02.2019.

Oxford English Dictionary (2019). https://en.oxforddictionaries.com/definition/hacker. Erişim Tarihi: 15.02.2019.

Oxford English Dictionary (2019). https://en.oxforddictionaries.com/definition/hacktivist. Erişim Tarihi: 13.02.2019 
Oxford English Dictionary (2019). https://en.oxforddictionaries.com/definition/hash. Erişim Tarihi: 18.02.2019

Oxford English Dictionary (2019). https://en.oxforddictionaries.com/definition/hashtag. Erişim Tarihi: 18.02.2019.

Oxford English Dictionary (2019). https://en.oxforddictionaries.com/definition/information. Erişim Tarihi: 05.03.2019.

Oxford English Dictionary (2019). https://en.oxforddictionaries.com/definition/slacker. Erişim Tarihi: 08.02.2019.

Oxford English Dictionary (2019). https://en.oxforddictionaries.com/definition/slacktivism. Erişim Tarihi: 08.02.2019.

Ruiz, P. (2016). The Cartographies of Protest. The Multidisciplinary Journal of Social Protest. Vol: 3 (2): 65-80.

Sert, N. Y. (Editör) (2016). Aktivizm-Toplumsal Değişimin Yeni Yüzü. İstanbul: Babil.

Shah, V. et al. (2013). The Era of Digital Activism. International Journal of Information Technology, Communications and Convergence, 2(4), 295-307.

Stache, L. C. (2014) Advocacy and Political Potential at the Convergence of Hashtag Activism and Commerce. Feminist Media Studies, 15(1), 162-164.

Türk Dil Kurumu (2019). Büyük Türkçe Sözlük. http://www.tdk.gov.tr/index.php?option=com_bts\& arama=kelime \&guid=TDK.GTS.5c55d08039b685.82689463 Erişim Tarihi: 02.01.2019.

Türk Dil Kurumu (2019). Büyük Türkçe Sözlük. http://www.tdk.gov.tr/index.php?option=com_bts\& arama=kelime\&guid=TDK.GTS.5c5b17fb511cb1.84585051 Erişim Tarihi: 02.01.2019.

Urban Dictionary (2019). https://www.urbandictionary.com/define.php?term=apptivism. Erişim Tarihi: 15.02.2019.

Van Dijk, J. (2016). A $\breve{g}$ Toplumu. Çeviren: Özlem Sakin. İstanbul: Kafka.

Yang, G. (2016). Narrative Agency in Hashtag Activism: The Case of \#Blacklivesmatter. Media and Communication, 4(4), 13-17.

Yegen, Ceren (2014). Bir Dijital Aktivizm Biçimi Olarak Slaktivizm: Change.Org Örneği. Karadeniz Teknik Üniversitesi İletişim Araştırmaları Dergisi, 8, 85-108.

Yıldırım, A. \& Şimşek, H. (2013). Sosyal Bilimlerde Araştırma Yöntemleri. Ankara: Seçkin.

Webb, M. (2013). Disciplining the Everyday State and Society? Anti-Corruption and Right to Information Activism in Delhi. Contributions to Indian Sociology, 47(3), 363-393.

-, (2019). https://avaaz.org/page/tr/. Erişim Tarihi: 07.02.2019.

-, (2019). https://www.care2.com. Erişim Tarihi: 07.02.2019.

-, (2019). https://www .change.org/about. Erişim Tarihi: 02.02.2019.

-, (2019). https://www .change.org/tr/başardıklarınız\#most-recent. Erişim Tarihi: 02.02.2019.

-, (2019). https://www.gopetition.com/about. Erişim Tarihi: 07.02.2019.

-, (2019). https://www.thepetitionsite.com. Erişim Tarihi: 07.02.2019. 